\title{
嗅覚受容体の応答特性と受容体制御による匂いの感じ方の変化 Suppression of Odors by Odorant Receptor Antagonists
}

\author{
難波 綾 \\ 花王株式会社 感性科学研究所 \\ 个 131-8501 \\ 東京都墨田区文花 2-1-3 \\ Aya KATO-NAMBA \\ Kao Corporation, Kansei Science \\ Research \\ 2-1-3, Bunka, Sumida-ku, Tokyo, \\ 131-8501, Japan \\ 中村 純二 \\ 花王株式会社 感性科学研究所 \\ T 131-8501 \\ 東京都墨田区文花 2-1-3 \\ Junji NAKAMURA \\ Kao Corporation, Kansei Science \\ Research \\ 2-1-3, Bunka, Sumida-ku, Tokyo, \\ 131-8501, Japan
}
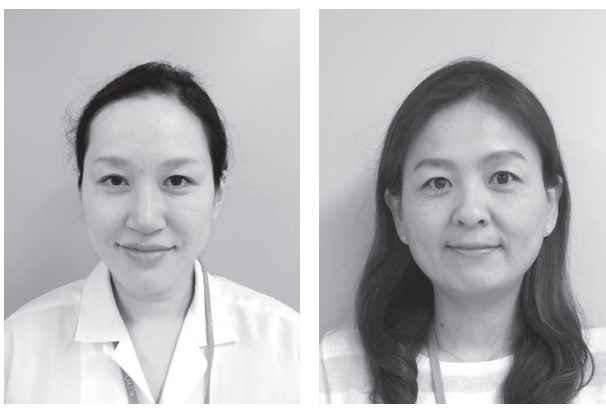

\author{
齋藤 菜穂子 \\ 花王株式会社 感性科学研究所 \\ 于 131-8501
}

東京都墨田区文花 2-1-3

Naoko SAITO

Kao Corporation, Kansei Science

Research

2-1-3, Bunka, Sumida-ku, Tokyo,

131-8501, Japan

論文要旨：我々の周りには常に匂いが存在する。匂い環境は決して一定ではなく，匂いを構成する分子の 種類も，その濃度も，刻一刻と変化する。匂いを察知するセンサーとして働くのが嗅覚受容体である。嗅覚 受容体は，G タンパク質共役型受容体に属し，ヒトでは 400 種ほどが機能していると考えられる。さて，匂 い分子と嗅覚受容体は複数対複数の組み合わせで対応付けられており，ある嗅覚受容体を活性化する匂い分 子が，他の嗅覚受容体に対してはアンタゴニストとして働き，嗅覚受容体の活性化を競合的に阻害すること が報告されている。本研究では, 受容体の応答強度と官能との関連を明らかにするために, ヘキサン酸を対 象にヒト嗅覚受容体ならびに受容体の応答を抑制するアンタゴニストの探索を行った。その結果, 複数のヒ 卜嗅覚受容体がへキサン酸に応答することが見出され，またへキサン酸受容体のアンタゴニストが複数同定 された。さらに、へキサン酸の受容体アンタゴニストにより，官能評価に扔いてもへキサン酸臭が低減する ことが示された。以上の結果は，末梢レベルで引き起こされる受容体応答と認知レベルで起こる匂いの感じ 方が関連していることを示すものである。

\begin{abstract}
The vertebrate olfactory system recognizes and discriminates between thousands of structurally diverse odorants. Detection of odorants in mammals is mediated by odorant receptors, which comprise the largest superfamily of G-protein coupled receptors (GPCRs). As with other GPCRs, OR ligands are able to serve as both agonists and antagonists. To understand the correlation of the function of odorant receptors and human olfaction, we examined effects of antagonists of human odorant receptors for odor intensity in sensory evaluation. Screening of odorant receptors for Hexanoic acid revealed that five ORs -OR2W1, OR10A6, OR51E1, OR51I2 and OR51L1- responded to Hexanoic acid dose-dependently, and also some antagonists that inhibited the response of Hexanoic acid-receptors were identified. Next, sensory evaluation was performed to examine whether antagonists of Hexanoic acid-receptors could decreased the Hexanoic acid-odor. As a result, it was found that antagonists weakened Hexanoic acid-odor, suggesting the link between the function of ORs at peripheral level and human olfaction at cognition level.
\end{abstract}

Key words: olfaction, odorant receptor, antagonist, agonist, hexanoic acid 


\section{1 はじめに}

みずみずしい果物の香りや顔をしかめたくなるような 悪臭など，我々の周りには実にさまざまな匂いが存在す る。多種多様な匂いを識別する匂いセンサーとして機能 しているのが, 嗅覚受容体 (odorant receptor) である。 嗅覚受容体は, 鼻腔に位置する嗅神経細胞 (olfactory sensory neuron）の繊毛（olfactory cilia）上に発現し, 匂いの情報を細胞内に伝達する役割を果たす（Fig. $1 \mathrm{~A})$ 。嗅覚受容体は Gタンパク質共役型受容体 (G-protein coupled receptor, GPCR) に属する膜タンパク質であり, ヒトでは 396 種類，マウスでは 1,035 種類存在する ${ }^{1)} 。$ この数は, ヒトの全遺伝子の約 $2 \%$ を占め, 非常に巨大 なタンパク質ファミリーとなっている。

多くの場合，匂いは複数の匂い分子から構成される。 一般的に匂い分子は，分子量 30３00 の低分子揮発性化 合物であり，世の中には数十万種もの匂い分子が存在す ると言われている。一方, 先述の通り, ヒトの鼻に存在 する嗅覚受容体は 396 種である。数十万種の匂い分子を 400 種ほどの嗅覚受容体で識別するために，匂い分子の 認識には「受容体コード」が用いられる。すなわち, 個々 の嗅覚受容体は構造の類似した複数の匂い分子を異なる

A

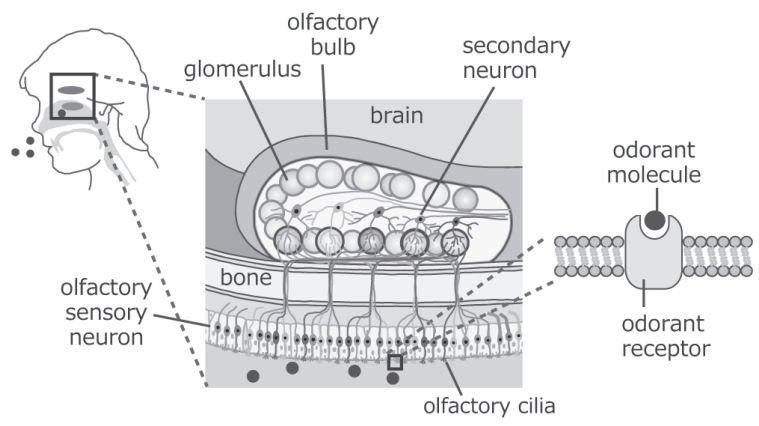

B

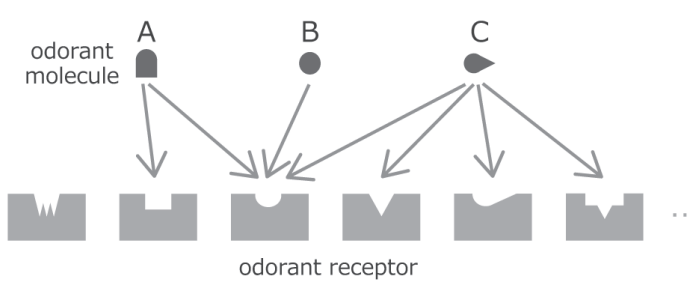

Fig. 1 Odorant recognition.

(A) Odorant recognition in human. Odorant molecules are recognized by odorant receptors, which are expressed in the olfactory cilia of olfactory sensory neuron. Olfactory sensory neurons project their axons to defined glomeruli within the olfactory bulb, and transmit odorant information to secondary neurons.

(B) Odorant receptor and olfactory coding. Each odorant molecule activates various odorant receptors, and each odorant receptor is activated by various odorant molecules.
親和性で認識し, 一方で個々の匂い分子は複数の嗅覚受 容体にそれぞれ異なる親和性で認識される ${ }^{2-4)}$ (Fig. 1B）。このように, 匂い分子と嗅覚受容体は複数対複数 の組み合わせで対応付けられており，それぞれの匂い分 子をバーコードのように嗅覚受容体の組み合わせで認識 することで，生物は膨大な匂い情報を処理していると考 えられる。

さて, 他の GPCR と同様に, 嗅覚受容体のリガンド には受容体を活性化する「アゴニスト」と, 受容体に結 合するが活性化しない「アンタゴニスト」が存在する (Fig. 2A)。アゴニストとアンタゴニストを混ぜた状態 で嗅覚受容体を刺激すると，アゴニストとアンタゴニス トが嗅覚受容体の結合ポケットを取り合うため, アゴニ ストによって引き起こされる嗅覚受容体の応答が抑制さ れることが報告されている ${ }^{5,6)}$ 。例えば，メチルイソオ イゲノールという匂い分子は, マウス嗅覚受容体 MOR204-34 に対しては受容体を活性化し応答を引き起 こすアゴニストとして作用するが，別の嗅覚受容体であ る mOR-EGに対してはアンタゴニストとして働き，ア

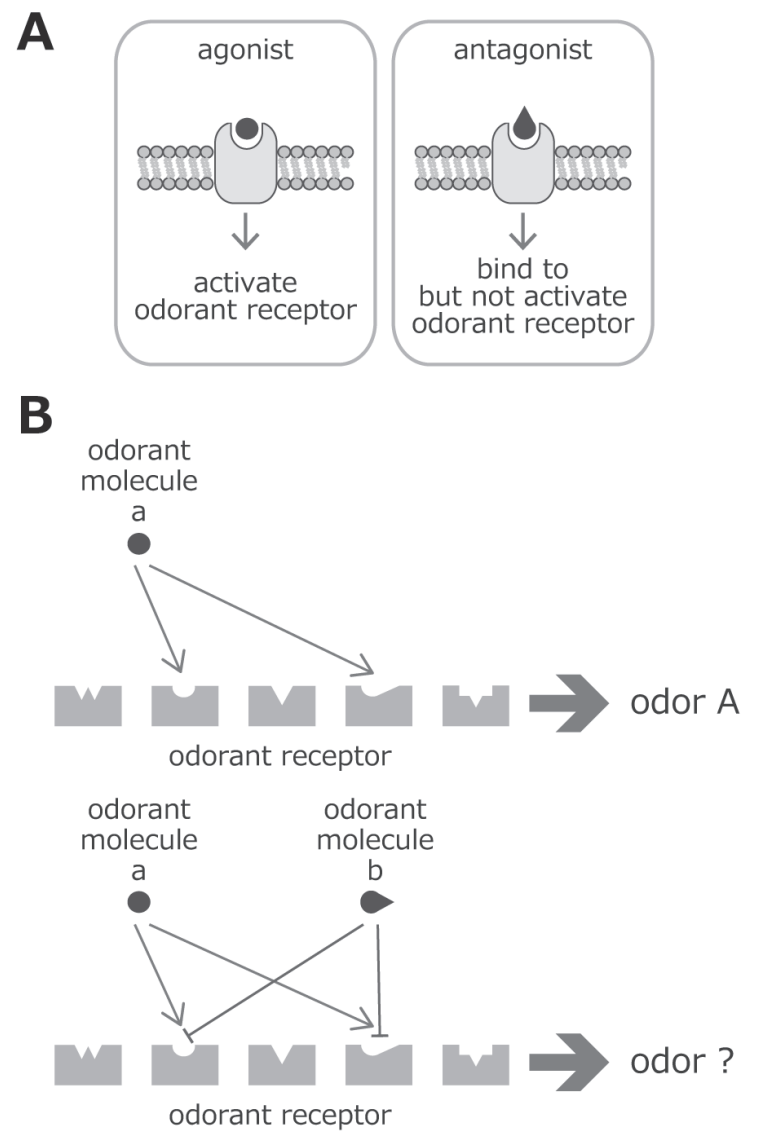

Fig. 2 Agonist and antagonist.

(A) Agonist and antagonist. An agonist binds to and activates a receptor. On the other hand, an antagonist binds to, but does not activate a receptor.

(B) The aim of this study. 
ゴニストであるオイゲノールの応答を抑制する ${ }^{6.7)}$ 。そ れでは，嗅覚受容体のアゴニストとアンタゴニストが共 に存在した場合, 官能評価においてヒトの匂いの感じ方 はどのように変わるのだろうか？ある匂い分子 $\mathrm{a}$ が存在 し，それにより匂い A が感じられるとする。ここに， 匂い分子 $\mathrm{a}$ を認識する嗅覚受容体のアンタゴニストであ る匂い分子 $\mathrm{b}$ を混合し受容体応答が抑制されると, 官 能レベルでも匂いが抑制されるのだろうか？(Fig. 2B)。

アンタゴニストによる匂いの感じ方の変化を明らかに するために，ここではへキサン酸を対象とし，へキサン 酸を認識する嗅覚受容体を特定するとともにへキサン酸 受容体のアンタゴニストを同定し, 官能評価によりアン タゴニストのヘキサン酸臭への影響を解析した。

\section{2 ヘキサン酸に応答する嗅覚受容体の応答特性 ${ }^{8)}$}

まずへキサン酸に応答する嗅覚受容体を明らかにする ために，全てのヒト嗅覚受容体を対象にへキサン酸応答 を測定した。測定手順を以下に説明する。まず，ヒト嗅 覚受容体 396 種をクローニングし，それぞれの嗅覚受容 体をヒト胎児腎蔵由来の培養細胞である HEK293 細胞 に発現させた。HEK293 細胞において，匂い分子により 嗅覚受容体が活性化すると，嗅覚受容体は HEK293 細 胞に内在的に発現している $\mathrm{G}$ タンパク質と共役し, ア デニル酸シクラーゼが活性化され細胞内 cAMP 量が増 加する。この cAMP 量の増加, すなわち嗅覚受容体の 活性化を発光強度として検出するルシフェラーゼアッセ イ法により，匂い応答を測定した（Fig. 3）。

最初に嗅覚受容体のヘキサン酸応答を測定した結果, OR2W1, OR10A6, OR51E1, OR51I2, OR51L1 という 5 種類の嗅覚受容体が, ヘキサン酸に対し濃度依存的な 応答を示すことが明らかとなった（Fig. 4A）。すなわち, ヒトがヘキサン酸の匂いを感知する際に，これらの 5 種 類の嗅覚受容体が関与することが明らかとなった。

次に，これらの嗅覚受容体が他の脂肪酸にどのような 応答を示すのか明らかにするために，炭素数 5 から 11 の脂肪酸に対する濃度依存的な応答を測定した。それぞ れの嗅覚受容体の応答闇值を Fig. 4B に示す。OR2W1 は炭素数 6〜9, OR10A6 はへキサン酸および炭素数 8〜 11, OR51E1 は炭素数 5〜11, OR51I2 は炭素数 5〜6, OR51L1 は炭素数 5～7 の直鎖脂肪酸に応答したことか ら, OR2W1 は中程度の鎖長の脂肪酸, OR10A6 は匂い 分子の中では比較的鎖長の長い脂肪酸，OR51I2 および OR51L1 は鎖長の短い脂肪酸に選択性が高いことが示唆 された。一方, OR51E1 は全ての脂肪酸に応答したこと から，脂肪酸認識において重要な役割を果たすことが示 唆された。

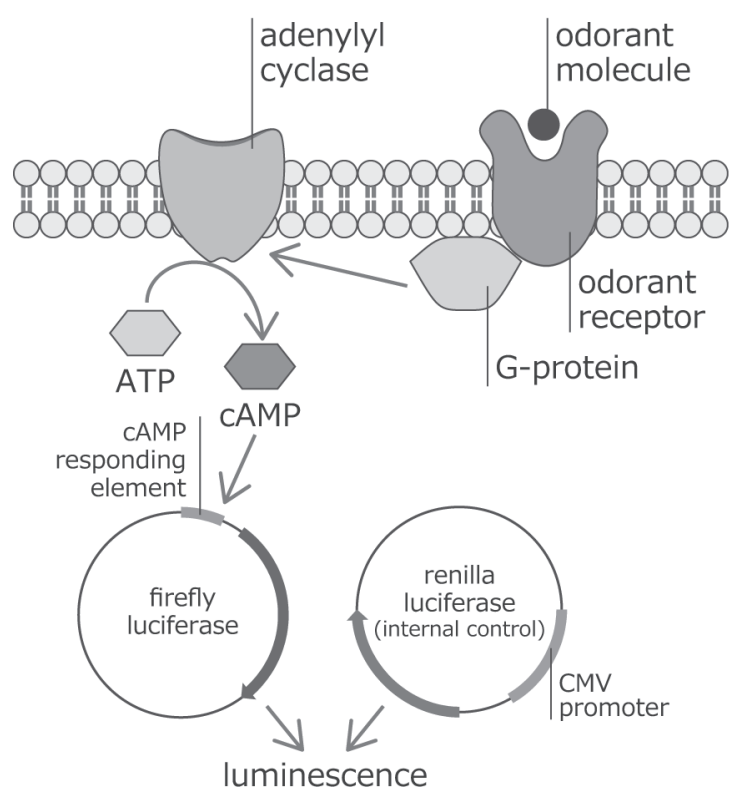

Fig. 3 Luciferase assay system.

When odorant molecules bind to and activate odorant receptors, intracellular cAMP level is increased. Increased cAMP activate cAMP responding element of firefly luciferase-expressing vector, resulting in expression of firefly luciferase. Renilla luciferase-expressing vector is also transfected into HEK293 cells as internal control to correct cell number and efficacy of transfection.

次に, 脂肪酸以外の匂い分子も対象にし, 各嗅覚受容 体の応答特性の解析を行った。アルコールやアルデヒド など様々な官能基を有し, 香調も多様である 149 種類の 匂い分子に対する応答を測定したところ，OR2W1なら びに OR10A6 は構造も香調も多様な非常に多くの匂い 分子に応答することが明らかとなった。一方, OR51E1 はどの匂い分子に対しても応答せず, OR51I2 はベンズ アルデヒドおよび2-メチル -2-ペンテン酸にのみ応答を 示した。OR51L1 はイソイースーパー（1- (1,2,3,4,5,6,7,8octahydro-2,3,8,8,-tetramethyl-2-naphthyl) ethan-1-one) および図中に示す共通構造を含む 5 種類の化合物に対し てのみ応答した（Fig. 5)。以上の結果から, OR2W1 お よび OR10A6はリガンド選択性が低く様々な匂い分子 に応答する嗅覚受容体, OR51E1, OR51I2, OR51L1は リガンド選択性が高く限られた匂い分子にのみ応答する 嗅覚受容体であることが示唆された。

\section{3 ヘキサン酸受容体のアンタゴニスト探索と官能評価 ${ }^{8}$}

これまでの実験により, ヘキサン酸に応答する 5 種類 の嗅覚受容体と, 各受容体の匂い分子に対する応答特性 を明らかにした。そこで最後に，ヘキサン酸受容体の応 答を抑制するアンタゴニスト探索を行った。HEK293 細 胞にへキサン酸受容体を発現させ, ヘキサン酸と候補分 

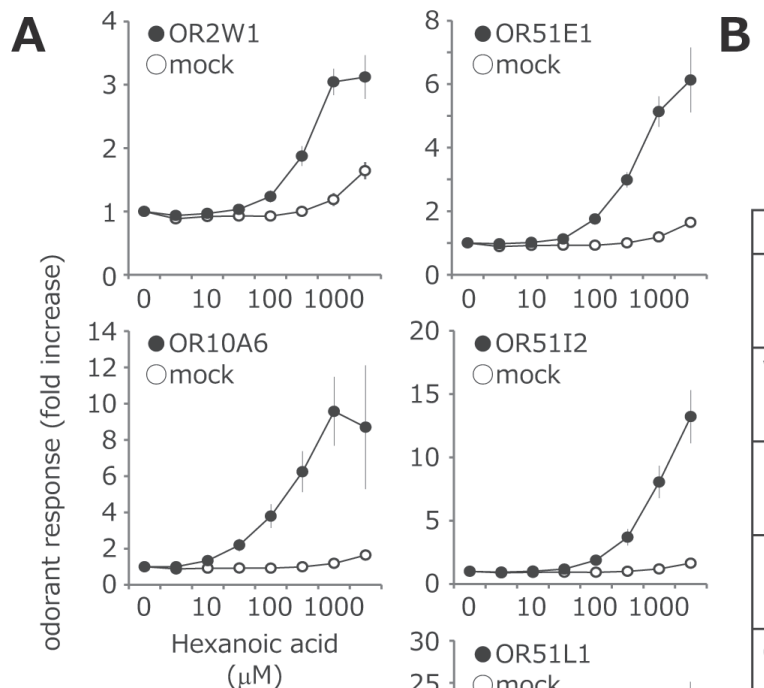

B

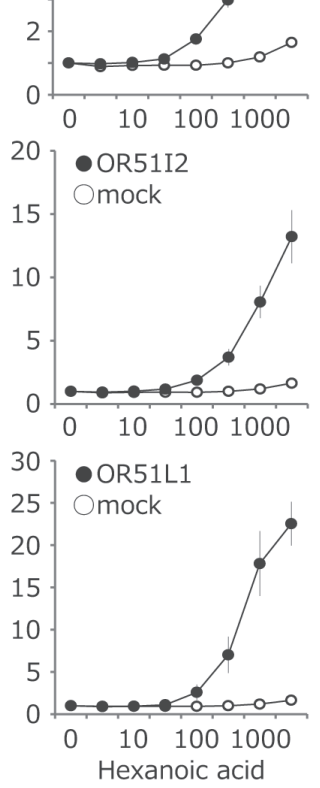

$(\mu \mathrm{M})$

\begin{tabular}{|c|c|c|c|c|c|}
\hline odorant molecule & $2 \mathrm{~W} 1$ & $10 \mathrm{~A} 6$ & $51 \mathrm{E} 1$ & 5112 & $51 \mathrm{~L} 1$ \\
\hline Isovaleric acid & & & 0 & & \\
\hline Valeric acid & & & ? & $\Omega$ & $\bullet$ \\
\hline Hexanoic acid & - & & - & - & 0 \\
\hline Heptanoic acid & - & & - & & - \\
\hline Octanoic acid & - & - & - & & \\
\hline Nonanoic acid & 0 & 0 & - & & \\
\hline Decanoic acid & & & 0 & & \\
\hline Undecanoic acid & & & & & \\
\hline
\end{tabular}

Fig. 4 Identification of Hexanoic acid-receptors and its response characteristic for fatty acids.

(A) Identified Hexanoic acid-receptors. Five odorant receptors- OR2W1, OR10A6, OR51E1, OR51I2, OR51L1- were expressed in HEK293 cells, and responses to Hexanoic acid (3, 10, 30, 100, 300, 1000, $3000 \mu \mathrm{M})$ were detected. X axis and Y axis were defined as the concentration of Hexanoic acid and intensity of odorant response, respectively. $\mathrm{n}=4, \pm \mathrm{SE}$.

(B) Response characteristics of Hexanoic acid-receptor for fatty acids. Response threshold of each Hexanoic acid-receptor was indicated as circle size.
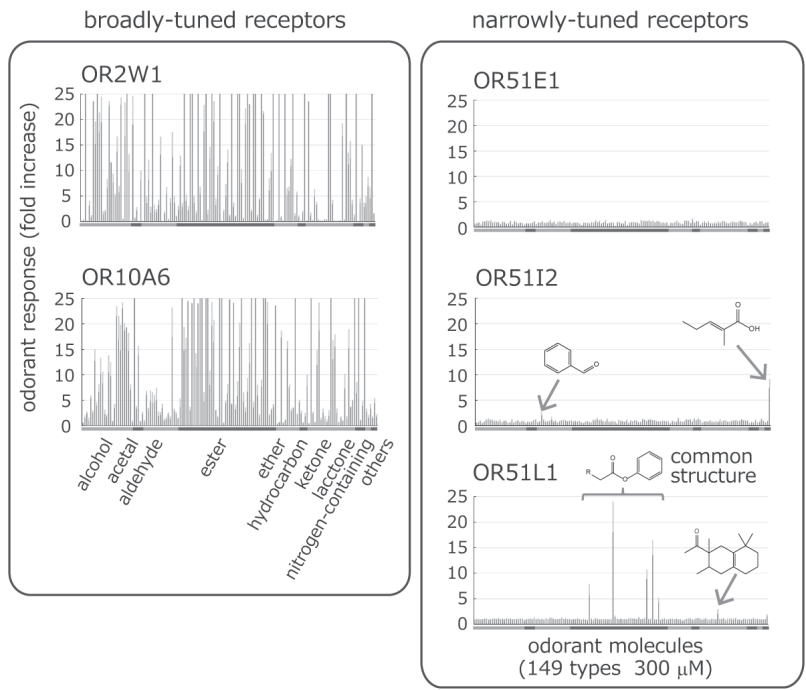

Fig. 5 Response characteristics of Hexanoic acid-receptors for various odorant molecules.

Five Hexanoic acid-receptors were expressed in HEK293 cells, and responses to various odorant molecules were analyzed. $\mathrm{X}$ axis and $\mathrm{Y}$ axis were defined as each odorant molecule (149 types) and intensity of odorant response, respectively. $n=3 \sim 5, \pm$ SE
子の混合物で刺激をし、へキサン酸応答を抑制する分子 を探索した。結果の一例を Fig. 6A に示す。OR51E1を 発現させた HEK293 細胞に対し, ヘキサン酸とフロル ヒドラール（Florhydral）の混合物で刺激を行うと，フ ロルヒドラールの濃度依存的にヘキサン酸応答が抑制さ れる。その抑制は非常に強く、へキサン酸 $1 \mathrm{mM}$ に対 してフロルヒドラール $300 \mu \mathrm{M}$ を混合することで, ヘキ サン酸 $1 \mathrm{mM}$ のみで刺激をした場合に比べ, 受容体応 答が $24 \%$ まで低下する。ヒドロキシシトロネラール (Hydroxy citronellal) は OR51E1 を弱く抑制し、へキ サン酸 $1 \mathrm{mM}$ にヒドロキシシトロネラール $300 \mu \mathrm{M}$ を混 合することで OR51E1 のへキサン酸応答が $63 \%$ まで低 下する。一方，トリプラール (Triplal) は OR51E1の ヘキサン酸応答に影響を与えないため, OR51E1 のアン タゴニストではないと判断される。OR51E1 のへキサン 酸応答を非常に強く抑制するフロルヒドラールは, OR5112 のヘキサン酸応答も非常に強く抑制し、ヘキサ ン酸 $1 \mathrm{mM}$ に対しフロルヒドラール $300 \mu \mathrm{M}$ を混合する ことで応答が $4 \%$ まで低下する。OR51I2 の応答はリリ アール（Lilial）によって弱く抑制され，マジャントー ル（Majantol）では抑制されない。このように，受容体 
A

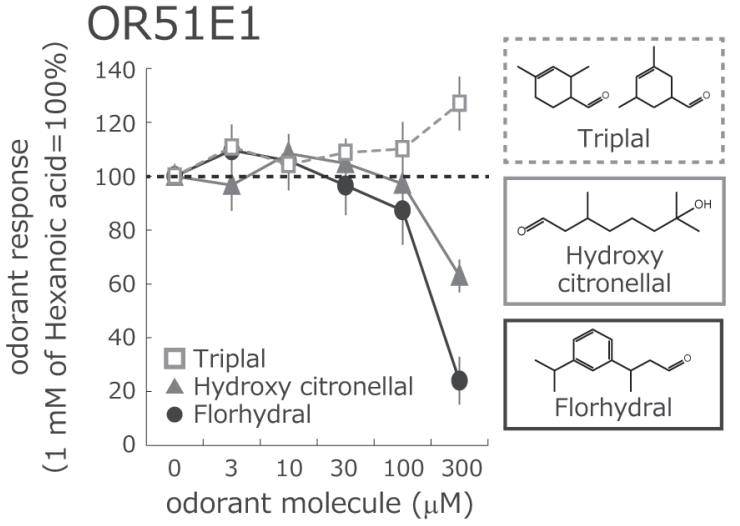

OR5112

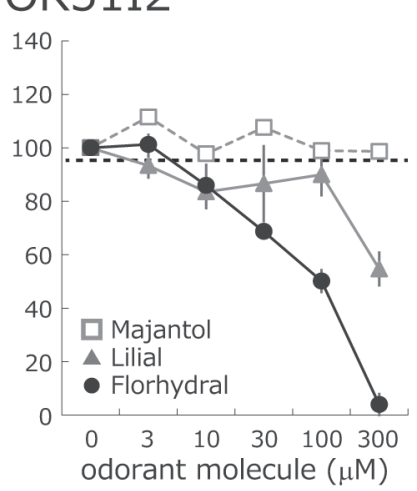

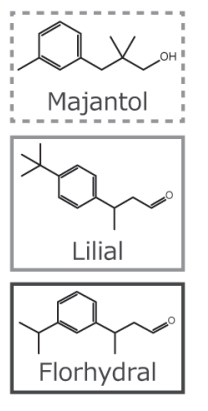

Intensity of Hexanoic acid odor

- inhibited receptor

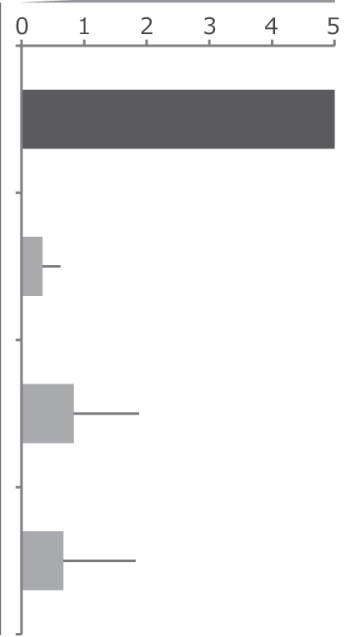

Fig. 6 Antagonist of Hexanoic acid receptors.

(A) Dose-dependent effects of Hexanoic acid-receptor antagonists. OR51E1 and OR51I2 were expressed in HEK293 cells, and antagonistic activity of each odorant molecule was analyzed. $\mathrm{X}$ axis indicated the concentration of odorant molecules, and Y axis was defined as intensity of odorant response, in which 100\% meant the activity for $1 \mathrm{mM}$ of Hexanoic acid. $\mathrm{n}=3 \sim 7, \pm \mathrm{SE}$, except for the response of OR51I2 to Hexanoic acid mixed with Majantol $(\mathrm{n}=1)$.

(B) Sensory evaluation of Hexanoic acid-odor. Filled circle 'O' indicated the receptor which could respond to Hexanoic acid. Horizontal line '-' meant the receptor which were inhibited by Florhydral, Bourgeonal or Isocyclocitral. The result of sensory evaluation was shown in the graph, in which ' 5 ' meant the intensity of odor of Hexanoic acid alone. $\mathrm{n}=3$, $\pm \mathrm{SD}$.

の抑制効果は匂い分子によってさまざまであり，複数の 嗅覚受容体のヘキサン酸応答を抑制する匂い分子もあれ ば，ある嗅覚受容体の応答は抑制するが別の嗅覚受容体 の応答は抑制しない它い分子も存在することが分かる。

140 種類の候補素材についてへキサン酸受容体のアン タゴニスト探索を行った結果, フロルヒドラール, ブル ゲオナール (Bourgeonal), イソシクロシトラール (Isocyclocitral) の 3 種類の香料が，ヘキサン酸受容体 を効率よく抑制することが示された（Fig. 6B）。具体的 には，フロルヒドラールおよびブルゲオナールでは, OR2W1, OR51E1, OR51I2, OR51L1のヘキサン酸応 答が抑制され，イソシクロシトラールでは OR2W1,
OR10A6，OR51E1，OR51L1のヘキサン酸応答が抑制 された。そこで,これらの香料を用い官能評価を行った。 ガラス瓶に 2 つ綿球を入れ，片方にはへキサン酸，も う片方にフロルヒドラール，ブルゲオナール，イソシク ロシトラールのいずれかを浸み込ませた。ガラス瓶の它 いを嗅ぎ、へキサン酸の它いの強さを評価した。その結 果, いずれの香料もへキサン酸の匂いを抑制することが 明らかとなった（Fig. 6B）。すなわち，末梢レベルでへ キサン酸受容体の応答を抑制するアンタゴニストは, 認 知レベルにおいてもへキサン酸の匂いを抑制することが 明らかとなり (Fig. 7), 嗅覚受容体の応答とヒトの官能 が関連していることが示唆された。 


\section{human} odorant receptors

Hexanoic acid
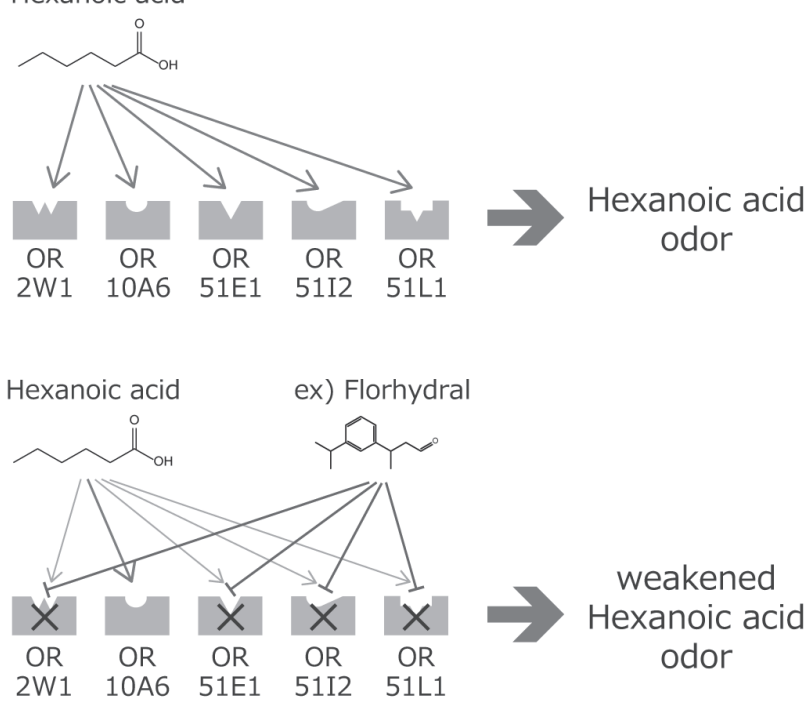

Fig. 7 The effect of antagonist on human olfaction. Antagonists of Hexanoic acid-receptor (ex: Florhydral) inhibited the response of Hexanoic acid-receptors, and weakend Hexanoic acid-odor.

\section{文 献}

1) Y. Niimura, Curr. Genomics, 13, 103 (2012).

2) B. Malnic, J. Hirono, T. Sato \& LB. Buck, Cell, 96, 713 (1999).

3) RC. Araneda, AD. Kini \& S. Firestein, Nat. Neurosci., 3, 1248 (2000).

4) K. Kajiya, K. Inaki, M. Tanaka, T. Haga, H. Kataoka \& K. Touhara, J. Neurosci., 21, 6018 (2001).

5) M. Spehr, G. Gisselmann, A. Poplawski, JA. Riffell, CH. Wetzel, RK. Zimmer \& H. Hatt, Science, 299, 2054 (2003).

6) Y. Oka, M. Omura, H. Kataoka \& K. Touhara, EMBO J., 23, 120 (2004).

7) Y. Oka, S. Katada, M. Omura, M. Suwa, Y. Yoshihara \& K. Touhara, Neuron, 52, 857 (2006).

8）難波（加藤）綾, 齋藤菜穂子, 近藤秀彦, 中村純二 AROMA RESEARCH, 15 (2), 48 (2014). 